also recommended. It was reported that the City Science and Commerce Library had been made a deposit library for the reports of the British Atomic Energy Research Establishment; the reports of the United States Atomic Energy Commission are already held in the library. All these reports are available for loan outside the area on payment of postage. The members of the Organization agreed to co-operate in the production and issue of additions to the "Research Bibliographies" prepared by the City Science and Commerce Library, the sixty-first of which, "Shell Moulding Practice (Croning or ' $\mathrm{C}$ ' Process)", has been in heavy demand from many parts of the world.

\section{Recording Photoelectric Photometer at Kodaikanal Observatory}

THERE are certain inherent disadvantages in using photographic photometry in the study of profiles of Fraunhofer lines, and workers in this field have felt the need for a spectrophotometric technique independent of the photographic process. When Brück was at Cambridge some years ago, he devised a photoelectric spectrophotometer using a vacuum photo-cell in conjunction with an electrometer triode; a recording photoelectric spectrophotometer has been built at the Kodaikanal Observatory on essentially similar lines and is described in a paper by $A$. $K$. Das, R. Ananthakrishnan and B. N. Bhargava, recently reprinted from the Indian Journal of Meteorology and Geophysics (2, No. 2; April 1951). The spectrum is provided by a high-dispersion prism spectrograph-a seven-prism instrument with a focal length of about $21 \mathrm{ft}$., giving a dispersion of $2 \cdot 4 \mathrm{~A}$. per $\mathrm{mm}$. in the region of the $D$ lines. The spectrograph is fed by an 18-in. siderostat through a 12-in. photovisual lens of focal length $21 \mathrm{ft}$. The upper half of the spectrum is focused on to the photographic plate and is used in the customary way, the lower half being deflected towards the side of the spectrograph camera by means of a right-angled prism. This is adjusted so that the deflected spectrum is also in focus at the scanning slit of the photometer. The light from this slit, which is about $0.03 \mathrm{~mm}$. wide, is received by a shortfocus convex lens fixed at a distance from the slit equal to its focal length. The parallel beam of light so obtained from a narrow section of the spectrum is directed again by a second right-angled prism to the photo-cell. The details of the instrument are shown by the three diagrams. Although primarily designed for use in solar line-contour work, its sensitivity can be easily reduced and thus its stability increased. For use in certain visual observations, a less sensitive prototype of the instrument has been constructed. It is suggested that a photometer of the type described could deal with various problems of interest to geophysicists.

\section{Sunspot Observations in Spain}

A summary of the observations made at Madrid Observatory during 1951 is given by E. Gullón in the Boletín Astranómico Del Observatorio De Madrid (4, No. $5 ; 1952)$. As in previous years, the observations were made with the Zeiss spectroscope, mounted in the equatorial Grubb telescope with object glass $20 \mathrm{~cm}$. aperture and focal length $3 \mathrm{~m}$. Six tables are puolished giving the usual details regarding the observations, and there are many illustrations showing large prominences at various times during the year. These are followed by a number of tables giving details of the observations of sunspots made in 1951 in the observatories of Madrid, Valencia, Cartuja (Granada) and Ebro. All the observations made at the different observatories have been sent each quarter to the International Bureau at Zurich, following the precedent of previous years.

\section{Factory Problems}

THE latest publication by the Institute of Personnel Management in its series of Occasional Papers is one by Wilfred Brown. The author is the managing director of the Glacier Metal Co., which, for many years, has been conducting a serious attempt to understand the managerial and social problems of to-day. In 1948 it undertook, with the Tavistock Institute of Human Relations, a joint sociological research into such matters. One of the results of this research has been the emergence of a series of defined ideas and concepts stating the social processes in use in its factories. The paper is an attempt to describe those ideas and concepts upon which. its leaders, managers, technicians, shop stewards and representatives are basing their methods of dealing with the day-to-day technical, economic, production and administrative problems encountered in operating the company. The Company is continuing its research activities in this field, and believes that the work so far done is but a start in the long process of achieving a greater degree of scientific objectivity in the social affairs of a factory. The paper, "Some Problems of a Factory", may be obtained from the Institute of Personnel Management, Management House, Hill Street, London, W.1.

\section{Courtaulds' Scientific and Educational Trust Fund : \\ Awards}

THE trustees of the Courtaulds' Scientific and Educational Trust Fund have announced the award for 1953 of the following postgraduate research scholarships in a branch of science related to the textile, plastics and allied industries, the awards being worth $£ 400$ and tenable for one year at the institute shown: D. W. Bannister, University of Oxford (renewal of 1952 award); C. S. Chadwick, Manchester College of Technology (renewal of 1952 award) ; P. G. Francis, University of Reading; A. J. Head, Birkbeck College, London; R. M. Hochstrasser, University of Edinburgh ; D. Margerison, University of Liverpool ; R. I. C. Michie, Manchester College of Technology; Miss E. R. Robertson, University College, Dundee; P. T. Speakman, University of Oxford (renewal of 1952 award) ; B. D. Stead, University of Birmingham (renewal of 1952 award) ; R. Stephens, University of Birmingham. Postgraduate research scholarships in textile technology, worth $£ 320$ for the first year and $£ 360$ for the second year (except where otherwise shown), have been.awarded as follows: C. B. Chapman, University of Leeds ; G. F. Cusick, Manchester College of Technology ; A. F. Greenwood, University of Leeds ; D. R. Hardisty, Manchester College of 'Technology ; F. K. Hall, University of Leeds (renewall of 1951 award for one term) ; H. B. Hallows, Manchester College of Technology (renewal of 1951 award for one year); G. M. Jeffrey, University of Leeds (renewal of 1951 award for one year).

\section{Eighth International Congress of Botany}

The Eighth International Congress of Botany will be held in Paris during July 2-14, 1954, in conjunction with the hundredth anniversary of the 